\title{
Effect of Internet Services on Customer's Online Purchase Intention (Case Study: Behpahksh Pharmaceutical Company)
}

\author{
Hooman Lajevardi ${ }^{*}$, Shahram Ghahramani ${ }^{2}$, Vahid Nasehifar ${ }^{1}$, Sara Pirmohammad ${ }^{3}$ \\ ${ }^{1}$ Faculty of Management and Accounting, Allameh Tabataba'i University, Tehran, Iran \\ ${ }^{2}$ Faculty of Management, University of Tehran, Tehran, Iran \\ ${ }^{3}$ Department of Management, Islamic Azad University Firuzkuh Branch, Iran
}

\section{ARTICLE INFO}

\section{Keywords:}

Transaction Services

Pre-purchase Services

Navigation Experience

Attitude to the web

Purchase Intention

\begin{abstract}
This research aimed at examining the effect of internet services on online purchase intention of customers in Behpakhsh Company. Variables of this study included transaction services, pre-purchase services, Navigation experience, Attitude to the web, online purchase intention. Descriptive-survey method was used to examine hypotheses and respond to the questions. Statistical population consisted of customers of Behpakhsh Company. Statistical sample size obtained to 384 members. This study was implemented in Behpakhsh Company. To collect required data, researcher-made questionnaire was used. Moreover, regression analysis was applied in this research. Data analysis and hypothesis testing were done through SPSS Software. Findings obtained from this study indicated effect of internet services on customers' online purchase intention in case of Behpakhsh Company.
\end{abstract}

\section{Introduction}

Online services have been developed as a sector without any substitute in the case of commercial and business fields so that the quality of online services has been more considered. In this regard, companies provide online services as a substitute for traditional offline services (Pujari, 2004). The reason for such a shift is that those businesses that provide top value, excellent services, and high-quality products can achieve customer loyalty which it will get much more benefit out of it (Otim and Grover, 2006). The case illustrates the enhanced level of transaction-dominant electronic services and we should know how services can obtain customer satisfaction by taking into consideration the operational and financial aspects (Zlqbal and Baran, 2003). According to Lai (2014), the swift progress of Information development and Communication (ICT) and E-commerce which allowed customers to purchase service and products online. Meanwhile, rapid enhancement of online sale has made an intense competition between electronic commerce providers who considers customer experience and mindset as a vital factor (Lai, 2004). The average accomplishment of numerous online service providers indicates a wide range of issues about customer behavior in the online services area. Marketing Science Institute (MSI) has established the research on customer recognition and customers' experiences through TIER (research priority 1) during 2014-2016. In particular, how digital technology changes the customer's experiences and way of thinking? According to Hackman and his colleagues (2006), "there are insufficient experimental researches in this field since it is not determined that whether previous factors of behavioral intentions created in offline situations could explain real and unexpressed behaviors of customers when these behaviors become compatible with online texture". Otim and Grover (2006) believe that web-based services are not enough developed and they should be more examined. In this regard, although

* Corresponding Author E-Mail Address: Lajevardi.hooman@gmail.com 
the services which are provided after product purchase are essential, businesses must think of steps taken in the past regarding the services that help customers improving their experiences making them focus on attitude toward network and purchase intention (Beykzad and Molavi, 2011). Quality of e-services has been expanding and most of the organizations are active in a competitive, dynamic, and changing environment since customers' satisfaction leads to increased efficiency, effectiveness, and profitability of economic organizations. Under such circumstances, organizations pay attention to improved quality of e-services in order to increase purchase rate and customer satisfaction. According to evidences, use of e-services and modern technologies in customer retention has a considerable effect on profit rate, growth of market contribution, reduce in costs, growth of stock price, decrease in customer escape, timesaving, and simple access to services (Jalilvand and Ibrahimi, 2011). In other words, it can be stated that satisfied customers are profitable sources for organization and promoted level of customers' satisfaction leads to increased profitability. Considering the importance of eservices' quality and its effect on customer purchase, this study was conducted to examine the effect of e-services on customers' online purchase intention regarding the case study of Behpakhsh Company.

\section{Materials and Methods}

\section{1) Research Literature}

\section{Purchase Intention}

Purchase intention is one of the main indicators to evaluate consumer behavior, which can indicate the probability of buying a product by consumers. The higher purchase intention depicts greater consumer readiness for a product (Toor et al., 2017). The term can be as a structural key in marketing research in various fields such as consumers' attitude, perceived value, perceived risk, usefulness, and ease of use (Faqih, 2013)

A consumer-brand engagement reveals the strong relationship between a brand and the consumer. The strength of this relationship determines the amount of resources which a consumer wants to allocate to a particular brand. Consumer-brand engagement is for human beings to develop physical relationships with specific individuals or objects as such the individuals then adapts themselves to the relations. Consumer-brand engagement and the level of resistance specify the link between consumer's self-image and how much the brand meets the individual's needs- either in the form of applied or experimental methods. As an example of this relationship, we can observe how relationship power affects positive thinking and feelings toward a brand and its relationship with personality. For consumers to develop a consumer-brand engagement, they need to identify a brand distinguishing them from their competitors (Hwang and Lee, 2017). Consumer-brand engagement is assumed to show a strategic necessity for generating superior organizational performance outcomes, including increased consumer loyalty, enhance in sales growth, superior competitive advantage, and increased profit; thus leading to greater competence in the future (Hollebeek et al., 2014)

Nowadays, businesses are looking for consumer engagement and interaction with their brands with an unprecedented rate. In spite of the great interest which exists among the experts, detailed investigations of the concept "consumer-brand engagement are only noticed in recent studies, causing a limited understanding of its current meaning. Recent research studies indicate that the consumer engagement is expected to develop an understanding of the consumer experience. Successful individuals can successfully engage consumers, create customer loyalty, and make benefits in predetermined classes, and provide further explanations of the growing professional interest in consumer engagement and their potential partnerships. In spite of a large number of advances in the professional environment, the scientific study of consumer engagement is lagged behind, providing a limited understanding of its current meaning (Verhoef et al., 2010). 


\section{On-Line Internet Services}

Internet has created a market in which, purchasers and the service providers expand their transactions in a direct manner and also mutually within a period outside of the physical spheres of traditional retails (Kiang and Shang, 2015). Developed use of IT in different parts of society, in particular in business scope, is resulted by IT capabilities. Ease of use of web-based electronic systems and reduced costs can be mentioned as some reasons for development of eservices (Wang and Lin, 2011). According to Kiang and Shang (2015), current studies have estimated a triple increase in the population of internet utilizers from roughly 300 million to a number upper than 1 billion during 2003 considering innovative solutions and high-Tech with online capabilities including wireless mobiles and digital-based smart TVs. In spite of the analytics related to internet expansion, there are not only prosperous but also unproductive options in marketing measurements through internet (Razavi, 2016). In opinion of Kiang and Shang (2015), purchase behaviors and online sellers play a vital role in success of retailers. If we are able to identify factors affecting purchasing decision of customer, retailers can design marketing strategies in order to fortify the customer experience and heighten total sale of products. The services associated with the customers is not a new thought, the modern businesses can utilize the new innovative High-Techs to make the electronic services experiences better than before (Brohman et al., 2015). Although there are some studies that increase customer experience providing online services, majority of these studies have confirmed effect of individual factors (Hung et al.,2014). In opinion of Yang and his colleagues (2004), majority of these studies applied traditional scales such as SERVQUAL. However, as researchers express, such scales are not enough to measure quality of services in all industries and situations or to define quality of online services. These tools ignore some important aspects of online services quality. Accordingly, this study was conducted based on the plan designed by Otim and Grover (2006) to examine effect of online services' levels in some textures without any transaction. For this purpose, two fundamental aspects of services provided through online manner are introduced as initial points including services provided before purchase and those related to the transaction associated with the services. According to Hosseini (2012), delivery of services through websites is related to an area in which, website facilitates effective sale, purchase, and delivery of products and services. The significant point to achieve success in virtual world is providing better online services. As Zeithaml et al. (2002) and Hung et al. (2014) express, qualitative delivery of services through websites is the main strategy for success that is possibly more important than lower price and website existence. These researchers showed that some service such as services related to navigation capabilities, efficiency, site beauty, and price information were important in online space besides some other significant dimensions in offline sale such as reliability, accountability, availability, insurance, customization, and characterization (Ramanathan, 2010). This case directs provided online sale services toward an integrated model to explain all effects that enables such services to concentrate and simulate online purchase intentions. According to Ohbyung and Nam Yeol Lee (2011), numerous hypotheses have been made to illucidate the reason and process of customers inclination to utilize the services based on web platform. Majority of mentioned theories raise structures to past models of thinking; in other words, Ohbyung and Nam Yeol Lee (2011) added familiarity and intimacy to the model of expectation-approval. Studies about e-services quality applied adjustments of measurement tools for services' quality that had been adopted from framework of traditional services' quality and developed them (Aghaei, 2009). However, a new vision should be provided in terms of important factors for web-based services' quality emphasizing on the issue how customers see services' quality before transaction (Van Beveren and Thomson, 2012). 


\section{Internet Services and Purchase Intention}

As it was mentioned, organizations should underpin a long-run strategic view to be present in international scenes. All organizations tend to sell their products or services considering customers' purchase intention (Ghazifard, 2012). In other words, customers should have purchase intention then organizations can sell their products or services. Therefore, awareness of factors affecting customers' purchase intention is a significant point in success of companies and organizations. One of factors affecting customers' purchase intention is e-services provided by the company. It should be stated that internet services and sale as well as electronic business will become first choices of companies in future considering facilitated sale operation and increased sale speed based on anticipations (Rezaei, 2013)

Laksamana (2018) in his study entitled "The Impact of Social Network Marketing on Purchase Intention and Brand Loyalty" presented some evidence from Indonesia's banking industry in order to detect the effects of marketing conducted via social network on the intention of customer for product purchase and his loyalty to a brand. Retailing was considered in this study, and 721 participants responded a questionnaire. Then the data were analyzed using structural equations with LISREL software. The results suggested that social network marketing led to purchase intention and brand loyalty.

Martins and his colleagues (2018) published an article entitled 'How smartphone's social network advertising affects consumers' purchase intentions', in which they researched the impact of smartphone's advertising on consumer purchase intentions in Portugal. They collected 303 questionnaires, and the data were analyzed using PLS software. They found out that social media advertising had a positive effect on consumers' shopping.

In the study conducted by Prasad Shantanu and his colleagues (2017) aiming to examine the effects of social media usage and electronic word-of-mouth with regard to the mediating role of trust in purchase-decision involvement, 212 questionnaires were collected; and the data were analyzed using structural equations. The results revealed that social media engagement and eword-of-mouth had affected the decision of purchase positively.

Considering the mentioned points and important role of e-services in position of companies and effect of customers' online purchase intention on success of companies in sale, this study was conducted to examine effect of online services on customers' online purchase intention. The significant issue of this study is to respond this question: can internet services effect on customers' online purchase intention in Behpakhsh Company?

\section{2) Methodology}

This is an applied study in terms of objective and a descriptive-survey research in terms of methodology. To collected required data about theoretical literature, library study was used. To collect data, questionnaire of effect of internet services on customers' online purchase intention was applied. Statistical population of study consisted of customers (unlimited members) of Behpakhsh Company, sample size obtained to 384 members. Simple random method was used as sampling method in this research. The questionnaires were distributed among statistical sample members then the data obtained from gathered questionnaires were analyzed through SPSS Software using regression correlation test to examine research questions and hypotheses.

\section{Research Hypotheses and Model}

To examine effect of internet service on customers' online purchase intention in Behpakhsh Company, the model presented by Kuster et al. (2016) was used (Figure 1). Depicting model in the following part, hypotheses adopted from the model were presented. 


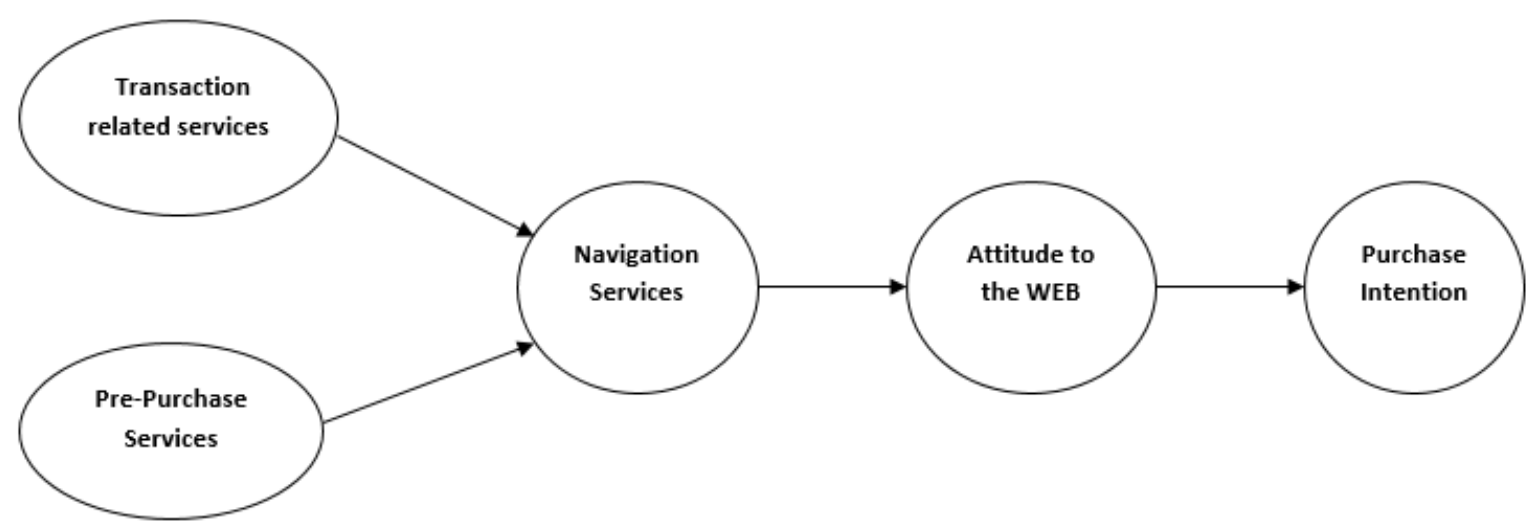

Figure 1. Conceptual Model; Source: Kuster et al. 2016.

\section{Hypotheses}

- Main Hypothesis:

Internet services can effect on customers' online purchase intention in Behpakhsh Company.

- Secondary Hypotheses:

1. Attitude to the web can effect on online purchase intention.

2. Navigation experience can effect on Attitude to the web.

3. Transaction services can effect on Navigation experience.

4. Transaction services can effect on Attitude to the web.

5. Pre-purchase service can effect on Navigation experience.

6. Pre-purchase services can effect on Attitude to the web.

\section{Results}

Regression test was used to examine hypotheses and questions.

3.1) Hypothesis 1: effect of Attitude to the web on online purchase intention

$\mathrm{H}_{0}$ : Attitude to the web cannot effect on online purchase intention.

$\mathrm{H}_{1}$ : Attitude to the web can effect on online purchase intention.

Table 1.

Effect of Attitude to the web on online purchase intention

\begin{tabular}{ccccccccc}
\hline Variable & $\mathbf{R}$ & $\mathbf{R}^{2}$ & $\mathbf{F}$ & $\mathbf{P}$ & $\mathbf{B}$ & $\boldsymbol{\beta}$ & $\mathbf{t}$ & $\mathbf{P}$ \\
\hline Attitude to the web & 0.728 & 0.529 & 429.659 & 0.0001 & 1.107 & 0.728 & 20.728 & 0.0001 \\
\hline
\end{tabular}

3.2) Hypothesis 2: effect of Navigation experience on Attitude to the web

$\mathrm{H}_{0}$ : Navigation experience cannot effect on Attitude to the web.

$\mathrm{H}_{1}$ : Navigation experience can effect on Attitude to the web.

Table 2.

Effect of Navigation experience on Attitude to the web

\begin{tabular}{ccccccccc}
\hline Variable & $\mathbf{R}$ & $\mathbf{R}^{\mathbf{2}}$ & $\mathbf{F}$ & $\mathbf{P}$ & $\mathbf{B}$ & $\boldsymbol{\beta}$ & $\mathbf{t}$ & $\mathbf{P}$ \\
\hline $\begin{array}{l}\text { Navigation } \\
\text { experience }\end{array}$ & 0.591 & 0.349 & 205.130 & 0.0001 & 0.366 & 0.591 & 14.322 & 0.0001 \\
\hline
\end{tabular}

3.3) Hypothesis 3: effect of transaction services on Navigation experience

$\mathrm{H}_{0}$ : transaction services cannot effect on Navigation experience.

$\mathrm{H}_{1}$ : transaction services can effect on Navigation experience. 
Table 3.

Effect of transaction services on Navigation experience

\begin{tabular}{ccccccccc}
\hline Variable & $\mathbf{R}$ & $\mathbf{R}^{\mathbf{2}}$ & $\mathbf{F}$ & $\mathbf{P}$ & $\mathbf{B}$ & $\boldsymbol{\beta}$ & $\mathbf{t}$ & $\mathbf{P}$ \\
\hline $\begin{array}{c}\text { transaction } \\
\text { services }\end{array}$ & 0.844 & 0.713 & 946.937 & 0.0001 & 1.227 & 0.844 & 30.772 & 0.0001 \\
\hline
\end{tabular}

3.4) Hypothesis 4: effect of transaction services on Attitude to the web

$\mathrm{H}_{0}$ : transaction services cannot effect on Attitude to the web.

$\mathrm{H}_{1}$ : transaction services can effect on Attitude to the web.

Table 4.

Effect of transaction services on Attitude to the web

\begin{tabular}{ccccccccc}
\hline Variable & $\mathbf{R}$ & $\mathbf{R}^{2}$ & $\mathbf{F}$ & $\mathbf{P}$ & $\mathbf{B}$ & $\boldsymbol{\beta}$ & $\mathbf{t}$ & $\mathbf{P}$ \\
\hline $\begin{array}{c}\text { transaction } \\
\text { services }\end{array}$ & 0.538 & 0.289 & 155.522 & 0.0001 & 0.484 & 0.538 & 12.471 & 0.0001 \\
\hline
\end{tabular}

3.5) Hypothesis 5: effect of pre-purchase services on Navigation experience $\mathrm{H}_{0}$ : pre-purchase services cannot effect on Navigation experience.

$\mathrm{H}_{1}$ : pre-purchase services can effect on Navigation experience.

Table 5.

Effect of pre-purchase services on Navigation experience

\begin{tabular}{ccccccccc}
\hline Variable & $\mathbf{R}$ & $\mathbf{R}^{2}$ & $\mathbf{F}$ & $\mathbf{P}$ & $\mathbf{B}$ & $\boldsymbol{\beta}$ & $\mathbf{t}$ & $\mathbf{P}$ \\
\hline $\begin{array}{c}\text { pre-purchase } \\
\text { services }\end{array}$ & 0.582 & 0.339 & 165.871 & 0.0001 & 0.783 & 0.582 & 13.995 & 0.0001 \\
\hline
\end{tabular}

3.6) Hypothesis 6: effect of pre-purchase services on Attitude to the web $\mathrm{H}_{0}$ : pre-purchase services cannot effect on Attitude to the web.

$\mathrm{H}_{1}$ : pre-purchase services can effect on Attitude to the web.

Table 6.

Effect of pre-purchase services on Attitude to the web

\begin{tabular}{ccccccccc}
\hline Variable & $\mathbf{R}$ & $\mathbf{R}^{2}$ & $\mathbf{F}$ & $\mathbf{P}$ & $\mathbf{B}$ & $\boldsymbol{\beta}$ & $\mathbf{t}$ & $\mathbf{P}$ \\
\hline $\begin{array}{c}\text { pre-purchase } \\
\text { services }\end{array}$ & 0.915 & 0.837 & 1963.650 & 0.0001 & 0.762 & 0.915 & 44.313 & 0.0001 \\
\hline
\end{tabular}

3.7) Main Hypothesis: effect of internet services on customers' online purchase intention $\mathrm{H}_{0}$ : internet services cannot effect on customers' online purchase intention.

$\mathrm{H}_{1}$ : internet services can effect on customers' online purchase intention

Table 7.

Effect of internet services on customers' online purchase intention

\begin{tabular}{cccccccccc}
\hline Variable & $\mathbf{R}$ & $\mathbf{R}^{\mathbf{2}}$ & $\mathbf{F}$ & $\mathbf{P}$ & $\mathbf{B}$ & $\boldsymbol{\beta}$ & $\mathbf{t}$ & $\mathbf{P}$ \\
\hline internet services & 0.899 & 0.809 & 400.391 & 0.0001 & 0.768 & 0.692 & 0.889 & 0.0001 \\
\hline
\end{tabular}

\section{Discussion}

According to table 1, Attitude to the web can predict online purchase intention so that $52.9 \%$ of variance of online purchase intention is explained by Attitude to the web and Attitude to the web can predict online purchase intention. Considering correlation coefficient of $\mathrm{R}=0.728, \mathrm{t}$ value above 1.96 and sig level of $\mathrm{P}<0.05$, hypothesis 1 was confirmed; therefore, it can be stated that Attitude to the web can effect on online purchase intention. 
According to table 2, Navigation experience can predict Attitude to the web so that $34.9 \%$ of variance of Attitude to the web is explained by Navigation experience and Navigation experience can predict Attitude to the web. Considering correlation coefficient of $\mathrm{R}=0.591, \mathrm{t}$ value above 1.96 and sig level of $\mathrm{P}<0.05$, hypothesis 2 was confirmed; therefore, it can be stated that Navigation experience can effect on Attitude to the web.

According to table 3, transaction services can predict Navigation experience so that $71.3 \%$ of variance of Navigation experience is explained by transaction services and transaction services can predict Navigation experience. Considering correlation coefficient of $\mathrm{R}=0.844, \mathrm{t}$ value above 1.96 and sig level of $\mathrm{P}<0.05$, hypothesis 3 was confirmed; therefore, it can be stated that transaction services can effect on Navigation experience.

According to table 4, transaction services can predict Attitude to the web so that $28.9 \%$ of variance of Attitude to the web is explained by transaction services and transaction services can predict Attitude to the web. Considering correlation coefficient of $\mathrm{R}=0.538$, $\mathrm{t}$ value above 1.96 and sig level of $\mathrm{P}<0.05$, hypothesis 4 was confirmed; therefore, it can be stated that transaction services can effect on Attitude to the web.

According to table 5, pre-purchase services can predict Navigation Experience so that 33.9\% of variance of Navigation Experience is explained by pre-purchase services and pre-purchase services can predict Navigation experience. Considering correlation coefficient of $R=0.582, t$ value above 1.96 and sig level of $\mathrm{P}<0.05$, hypothesis 5 was confirmed; therefore, it can be stated that pre-purchase services can effect on Navigation experience.

According to table 6, pre-purchase services can predict Attitude to the web so that $83.7 \%$ of variance of Attitude to the web is explained by pre-purchase services and pre-purchase services can predict Attitude to the web. Considering correlation coefficient of $\mathrm{R}=0.915, \mathrm{t}$ value above 1.96 and sig level of $\mathrm{P}<0.05$, hypothesis 6 was confirmed; therefore, it can be stated that prepurchase services can effect on Attitude to the web.

According to table 7, internet services can predict customers' online purchase intention so that $80.9 \%$ of variance of customers' online purchase intention is explained by internet services and internet services can predict customers' online purchase intention. Considering correlation coefficient of $\mathrm{R}=0.899, \mathrm{t}$ value above 1.96 and sig level of $\mathrm{P}<0.05$, main hypothesis was confirmed; therefore, it can be stated that internet services can effect on customers' online purchase intention in Behpakhsh Company.

\section{Conclusion}

Since online purchases and internet services have been using increasingly over the recent years, those individuals who use this communicational channel as a tool for marketing and selling products and services have found that delivery and quality of services as an important factor in this field. In this regard, following recommendations are proposed based on the obtained results in order to improve internet services and impact on customer purchase:

- All customers of internet stores tend to know the certain time of product delivery; hence, certain time of product delivery should be explained in website. For instance, you can present a separate page and explain about the mentioned details.

- Product sending and returning policies should be transparent since such transparency in policies related to sending or returning products of every physical or online store is related to product returning policies and rules and such rules are important in online shopping. The importance of product returning in an online store is a guarantee provided to user so that if the sent product is different from seen product in store in terms of appearance and specifications then the delivered product can be returned. Therefore, such policies should be determined precisely to strengthen credit of store. In addition, some specifications such as returning the product during a certain time interval or in case of customer dissatisfaction can be an incentive 
plan for customers of online store. Online shopping or selling is beyond adding a product to the website.

- The website should notify of changes related to delivery time and other changes. website should be designed in a way that purchaser feel secure when buying online; in this regard, conditions of filling out purchase process and forms should be determined and website should be designed in a way that purchaser feel comfortable.

- Some specific products should be introduced in different events preparing a special package of products. This action makes your website dynamic and introduces you as an active store from customers' perspective. This method makes the customer uses specific services of your website voluntary.

- Many of customers tend to order some products that can be delivered as soon as possible paying the cost of such speed; however, this should be a reasonable cost. Some tend to receive the product at the lowest price and time is not an important factor for them. Hence, a perfect online store should design both models for customers signing contracts with companies that consider both methods of low cost and low time.

- Free product delivery is one of the most significant discount methods in online store. Some other methods include sending gift and discounting cards for repurchase besides delivered products, use of a discount percent for a collection of products.

- When a product is showing to a customer, complementary products should be also shown. The best place and time for such collection is the certain time registered by the customer when is reading details of primary product.

- Appreciating the customer for his her purchase is a positive reaction so that such appreciate should be shown to customer. In case of online sale of products or service, it should be done as discount given in next purchases, sending specific gifts besides the main product and other actions. Appreciate the customers and remain in their minds.

- The screen of website is responsible for the product despite the different path selected by customer to find considered product; in this regard, the website should give a suitable explanation to reviewer making himlher a customer. Some options such as exact explanation of facilities, proper display of features, and use of high-quality images to make customers aware play a vital role in this field. Virtual environment of purchase may show images more highlighted so it is recommended using video.

- A successful e-commerce is directly related to trust ratio of customer. Creation of an honest communication between you and your customers plays a vital role in your business. Some presented methods consist of correct details without any exaggeration in profile pages of organization. A link entitled "about us" exists in many of websites that is not correctly used unfortunately. There are some pages that make a mutual trust between customers and website owners; these pages can be named as contact information, customer services, response to questions, and many other options.

- In every business, in particular e-commerce, opinions of users is the most important factor affecting that business. You should respect users' opinion preparing better conditions for them. Many of advanced commercial websites have focused on effect of services provided in site and analysis of positive or negative feedbacks of users.

- Finally, you should know that quality of services and products is the fundamental basis in every e-commerce. In fact, quality is a factor that helps you to sell your products or services.

\section{References}

Aghaei, S. J. (2009). Entrepreneurial marketing, Tehran, Danesh Pajoohan Publications, First Edition. 
Beykzad, J., Molavi, Z. (2011). The relationship between quality of e-services and electronic satisfaction of students of Islamic Azad University Bonab Branch, Journal of Information and Communication Technology in Educational Sciences, 67-93. http://dx.doi.org/10.1016/j.ijme.2016.04.003

Brohman, K., Parasuraman, A., \& Watson, R. (2015). Internet-Based customer Service systems: What are they and when are they successful? In new meanings for marketing in a new millennium. 150-153. https://doi.org/10.1007/978-3-319-11927-4_45

Faqih, K. (2013). Exploring the influence of perceived risk and internet self-efficacy on consumer online shopping intentions: Perspective of technology acceptance model. International Management Review, 9(1), 68-78.

Ghazifard, A. M. (2012). Evaluating the effect of e-service quality on customer satisfaction and re-purchase intention (Case Study: Mellat Electronic Payment Company).

Hackman, D., Gundergan, S., Wang, P. \& Daniel, K. (2006). A service perspective on modeling intentions of on-line purchasing. Journal of Services Marketing, 20 (7), 459- 470. https://doi.org/10.1108/08876040610704892

Hollebeek, LD, Glynn, MS \& Brodie, RJ (2014). Consumer brand engagement in social media: Conceptualization, scale development and validation', Journal of Interactive Marketing, 28 (2), 149-165. https://doi.org/10.1016/j.intmar.2013.12.002

Hosseini, M. (2012). Assessment of the willingness and loyalty of potential customers to purchase from online stores, Strategic Management Studies, 167-188.

Hung, S., Chen, C., \& Huang (2014). An integrative approach to understanding Customer satisfaction with e-Service of online stores. Journal Of electronic commerce Research, 15(1), 40-57.

Hwang, J., \& Lee, K. W. (2017). The antecedents and consequences of golf tournament spectators' memorable brand experiences. Journal of Destination Marketing \& Management. https://doi.org/10.1016/j.jdmm.2017.09.001

Jalilvand, M., Ibrahimi, A. (2011). The effect of mouth communications on the purchase of domestic automobiles (Case Study: Samand Vehicle Iran Khodro Co.), Commercial Management Journal. https://doi.org/10.1108/02634501211231946

Kiang, M., \& Shang (2015). Online purchase decision and its implication on E-Tailing strategies. In New Meanings for marketing in a new millennium. 212-217. https://doi.org/10.1007/978-3-319-11927-4_67

Kuster, I. Vila, N. Canales, P. (2016). How does the online service level influence consumers' purchase intentions before a transaction? A formative approach", European Journal of Management and Business Economics, 25(3), 111-120. https://doi.org/10.1016/j.redeen.2016.04.001

Kwon, O., Lee, N. Y. (2011). A relationship-aware methodology for context-aware service selection. Expert Systems 28(4), 375-390. https://doi.org/10.1111/j.14680394.2010.00548.x

Lai, J. (2014). E-Servcon and e-Commerce success: Applying the delone \& Mclean model. Journal Of organizational and end user computing, 26(3), 1-22. https://doi.org /10.4018/joeuc.2014070101 
Laksamana, P. (2018). Impact of Social Media Marketing on Purchase Intention and Brand Loyalty: Evidence from Indonesia's Banking Industry. International Review of Management and Marketing, 8(1), 13-18.

Marketing Science Institute, 2014-2016 Research Priorities, www.msi.org

Martins, J., Costa, C., Oliveira, T., Gonçalves, R., \& Branco, F. (2018). How smartphone advertising influences consumers' purchase intention. Journal of Business Research. 94, 378-387. https://doi.org/10.1016/j.jbusres.2017.12.047

Otim, S., \& Grover, V. (2006). An empirical study on web-based services and customer loyalty. European Journal of Information Systems, 15, 527-541. https://doi.org/10.1057/palgrave.ejis.3000652

Prasad Shantanu, C Gupta Ishwar, K Totala Navindra, (2017). Social Media Usage, Electronic Word of Mouth and Purchase Decision Involvement, Asia-Pacific Journal of Business Administration, 9(2), 32-1. https://doi.org/10.1108/APJBA-06-2016-0063

Pujari, D. (2004). Self-Service with a smile? Self-Service technology (Sst) Encounters among Canadian business-To-Business. International Journal of service industry management, 15(2), 200-219. https://doi.org/10.1108/09564230410532510

Ramanathan, R. (2010). E-Commerce Success Criteria: Determining Which Criteria Count Most. Berlin: Springer. https://doi.org/10.1007/s10660-010-9051-3

Razavi, H. R. (2016). Investigating the impact of e-banking services on customer intention and their loyalty (studying the Pasargard Bank's website).

Rezaei, A. (2013). Factors affecting the value of online shopping and re-purchase intention of customer.

Toor, A. Husnain, M., Hussain T, (2017). The Impact of Social Network Marketing on Consumer Purchase Intention in Pakistan: Consumer Engagement as a Mediator. Asian Journal of Business and Accounting, 10(1), 167-199.

Van Beveren, J., \& Thomson, H. (2012). The Use of Electronic Commerce By SMEs In Victoria Australia. Journal of Small Business Management. 40 (3), 250-253. https://doi.org/10.1111/1540-627X.00054

Verhoef, PC, Reinartz, WJ \& Krafft, M (2010). Customer engagement as a new perspective in customer management, Journal of Service Research, 13(3), 247-252. https://doi.org/10.1177/1094670510375461

Wang, Y., \& Lin, H. (2011). Determinate of User Acceptance of Internet Banking: An empirical Study, International Journal of Service Industry Management. https://doi.org/10.1108/09564230310500192

Yang Z, Jun M, Peterson RT (2004). Measuring costumer perceived online service quality: Scale development and managerial implications. Int. J. Oper. Prod. Manage. 24(11/12), 1149-1174. https://doi.org/10.1108/01443570410563278

Zeithaml, V.A., Parasuraman, A., \& Malhotra, A. (2002). Service quality delivery through website: A critical review of extant knowledge. Journal of the Academy of Marketing Science, 30(4), 362-375. https://doi.org/10.1177/009207002236911

Zlqbal, R., \& Baran, R. (2003). Understanding consumer choices and preferences in Transaction-Based-Services. Journal of service research, 6(1), 51-65. https://doi.org/10.1177/1094670503254276 